\title{
Responses of Tswana goats to various lengths of water deprivation
}

\author{
T. Adogla-Bessa ${ }^{\#}$ and A.A. Aganga \\ Botswana College of Agriculture, Private Bag 0027 Gaborone, Botswana.
}

\begin{abstract}
The aim of this trial was to determine the water intake of Tswana goats and investigate the effects of short term water deprivation in summer or winter (6000 ml water offered either once every $72 \mathrm{~h}, 48 \mathrm{~h}, 24 \mathrm{~h}$ or ad libitum) on feed intake, dry matter digestibility, growth rate and health. Goats were fed a diet comprising $60 \%$ Cenchrus ciliaris hay and $40 \%$ Medicago sativa hay. Feed intake per kg metabolic weight was inversely related to water intake. Body weight gains decreased with longer watering intervals, rectal temperatures were unaffected but respiratory rate, packed cell volume, pulse rate, haemoglogin level and mean corpuscular haemoglobin concentration was highest with the $72 \mathrm{~h}$ watering interval. Feed intake and daily weight gains were higher in winter than summer, but animals drank more water in summer than in winter, and showed more signs of dehydration in summer. Dry matter digestibilities (\%) were 66.8, 66.7, 64.2 and 65.2 for water intake intervals of ad lib, $24 \mathrm{~h}, 48 \mathrm{~h}$ and $72 \mathrm{~h}$ respectively; digestibilities of organic matter, crude protein and crude fibre followed the same trend. Urine output, faecal output per kg metabolic weight and faecal moisture content decreased with increased length of water deprivation. It was concluded that Tswana goats are well adapted to semi-arid zones and can be watered once in $72 \mathrm{~h}$ without severe dehydration.
\end{abstract}

Keywords: Water, intake, digestibility, health, goat, ruminant

${ }^{\#}$ Author to whom correspondence should be addressed; present address: University of Ghana, Agricultural research station Legon, P O Box LG 68, Legon, Ghana; E-mail: agriclib@ libr.ug.edu.gh

\section{Introduction}

Botswana is a semi-arid country with low and erratic rainfall, and the scarcity of surface water limits the use of pastures and determines the availability of drinking water for animals. In addition to this, water intake is known to influence feed intake and digestibility. Goats are important ruminants in Botswana. The country has a goat population of 1.84 million, $80 \%$ of which are found in the traditional sector where formal management and housing is almost non-existent (CSO, 1995). These animals are subject to varying periods of water deprivation. Various reports on responses of ruminants to water deprivation in similar harsh environments have been published for West Africa (Aganga et al., 1988), East Africa (Schoen, 1968) and Southern Africa (Sibanda et al., 1997). However, information on the Tswana goat is limited and there are no published reports on the effects of water deprivation in Tswana goats. This study was designed to investigate the effect of restricted water intake during winter or summer on feed intake, nutrient digestibility and health of Tswana goats.

\section{Material and methods}

The study was conducted in Gaborone, located in the semi-arid south-east area of Botswana, and consisted of an intake trial and a digestion study. Twenty male Tswana goats, aged nine months at the start of the study, were used for the intake study which lasted for 365 days. There were four watering treatments with five replicates per treatment. Goats were offered $6000 \mathrm{ml}$ water either ad libitum, every $24 \mathrm{~h}$, every $48 \mathrm{~h}$ or every $72 \mathrm{~h}$. For the latter three treatments, the water allocation was offered during two periods of two hours each during which the animals were allowed to drink to satiety. The amounts of feed and water consumed were recorded every morning before fresh feed and water was offered. Evaporative water loss was determined by placing six litres of water in empty pens to simulate prevailing conditions. Water intake was adjusted for evaporative loss. Animals were housed in individual pens and fed a diet consisting of $60 \%$ Cenchrus ciliaris hay (buffalo grass) and $40 \%$ Medicago sativa (lucerne) hay at a level of $4 \%$ of body weight (dry matter basis). A mineral supplement was freely available. The volume of water ingested with the diet was estimated from the dry matter content of the roughage. Animals were weighed every two weeks and monthly measurements were made for rectal temperature, pulse rate, packed cell volume (PCV), haemoglobin $(\mathrm{Hb})$ and mean corpuscular haemoglobin concentration (MCHC).

The digestibility experiment was conducted using feed and watering treatments identical to that used in the intake study. Sixteen castrated Tswana goats (average weight $26.9 \mathrm{~kg}$ ), were randomly allocated to watering treatments and confined in metabolism crates. There were four replicates per treatment. Digestibility was measured over a 21-day period following a 14-day adjustment period. Faeces were collected daily, weighed and a $2 \%$ sub-sample stored at $5^{0} \mathrm{C}$. Stored faeces were bulked on weekly basis, oven dried at $70^{\circ} \mathrm{C}$ and ground for laboratory analysis. Urine was collected daily. 
Toluene ( $25 \mathrm{ml})$ and sulphuric acid ( $25 \mathrm{ml}$ of a $50 \%$ solution) were added to the urine collection vessels every morning to prevent evaporation and to maintain acidity at $\mathrm{pH} 3$. The volume of urine was measured daily and a $50 \mathrm{ml}$ sub-sample was taken and stored at $5^{\circ} \mathrm{C}$ and then bulked on weekly basis. Dry matter (DM), ash, crude protein (CP) and crude fibre (CF) content of both feed and faeces was determined (AOAC, 1995). The experimental design was a completely randomised design and results were subjected to analysis of variance and regression analysis (SAS, 1990; Mead \& Curnow, 1992).

\section{Results and discussion}

The mean minimum and maximum environmental temperature and relative humidity for both experiments is shown in Table 1. The composition of the diet is presented in Table 2. There were interaction effects for total water intake per $\mathrm{kg}$ metabolic weight $\left(\mathrm{W}^{0.75}\right)$, total water intake and free water intake $(p<0.05)$. The $\mathrm{F}$-values in the analysis of variance, however, showed that interaction effects were small and were far outweighed by the main effects; therefore only main effects are discussed here.

Table 1 Mean temperatures and relative humidity at the experimental site during the intake and digestion studies

\begin{tabular}{lllll}
\hline & \multicolumn{2}{l}{ Temperature $\left({ }^{\circ} \mathrm{C}\right)$} & \multicolumn{2}{l}{ Relative humidity $(\%)$} \\
Intake & $\begin{array}{l}\text { Digestion } \\
\text { trial }\end{array}$ & Intake trial & $\begin{array}{l}\text { Digestion } \\
\text { trial }\end{array}$ \\
\hline Minimum & 2.8 & 19.6 & 46 & 39 \\
Maximum & 34.1 & 34.1 & 66 & 65 \\
\hline
\end{tabular}

Table 2 Composition of experimental diet (60\% Cenchrus ciliaris, 40\% Medicago sativa) Tswana goats subject to varying lengths of water deprivation

\begin{tabular}{ll}
\hline Components & Content $(\%)$ \\
\hline Dry matter & 91.6 \\
Crude protein & 11.1 \\
Crude fibre & 37.6 \\
Ash & 11.8 \\
Phosphorus & 0.19 \\
Calcium & 0.64 \\
\hline
\end{tabular}

Feed intake, water consumption and animal performance are shown in Table 3. Feed intake per kg metabolic weight increased ( $p<0.01$ ) as water intake decreased from the $a d$ lib to the $72 \mathrm{~h}$ watering interval. The $a d$ lib and $24 \mathrm{~h}$ treatments did not differ but were lower $(p<0.05)$ than the $48 \mathrm{~h}$ and $72 \mathrm{~h}$ treatments which also did not differ from each other $(p>$ $0.05)$. When feed intake was regressed on water intake using pooled data, the correlation was negative $\left(\mathrm{R}^{2}=0.20 ; p<0.01\right)$. This implies that $20 \%$ of the variation in feed intake was due to amount of water ingested. This is reflected in water to feed intake ratios which decreased ( $p<0.01$ ) from 2.6 ( $\mathrm{ad}$ lib) to 1.5 (72 $\mathrm{h}$ treatment). Neither efficiency of feed conversion nor average daily weight gain differed $(p>0.05)$ between the $a d l i b$ and $24 \mathrm{~h}$ treatments or between the $48 \mathrm{~h}$ and $72 \mathrm{~h}$ treatments, but the former two were higher than the latter two $(p<0.01)$. A decrease in water to feed ratio with increasing watering interval was also reported by Ikhatua et al. (1985) working with bulls and Utley et al. (1970), but contradicts findings by Aganga et al. (1988). This increase in feed intake with reduced water consumption could be due to an increase in the space available for feed in the reticulo-rumen, as Campling et al. (1961) have shown a direct relationship between rumen fill and intake in cows fed hay. 
Table 3 Intakes of feed and water and weight gain of Tswana goats subject to varying lengths of water deprivation

\begin{tabular}{llllll}
\hline & \multicolumn{5}{c}{ Watering interval } \\
& ad lib & $24 \mathrm{~h}$ & $48 \mathrm{~h}$ & $72 \mathrm{~h}$ & s.e. \\
\hline Feed intake (g DM/day) & 762 & 743 & 742 & 758 & 15.9 \\
Liveweight (kg) & $36.1^{\mathrm{a}}$ & $34.7^{\mathrm{b}}$ & $31.3^{\mathrm{b}}$ & $31.3^{\mathrm{b}}$ & 1.02 \\
Feed intake (g DM/kgW $\left.{ }^{0.75}\right)$ & $55.1^{\mathrm{b}}$ & $55.5^{\mathrm{b}}$ & $58.9^{\mathrm{a}}$ & $60.2^{\mathrm{a}}$ & 1.13 \\
Free-water intake (ml/day) & $1895^{\mathrm{a}}$ & $1785^{\mathrm{a}}$ & $1259^{\mathrm{b}}$ & $1047^{\mathrm{c}}$ & 48.9 \\
Feed-water intake (ml/day) & 64.0 & 62.4 & 62.4 & 63.6 & 1.34 \\
Total water intake (ml/day) & $1960^{\mathrm{a}}$ & $1847^{\mathrm{a}}$ & $1321^{\mathrm{b}}$ & $1111^{\mathrm{c}}$ & 49.6 \\
Total water intake (ml/kgW $\left.{ }^{0.75}\right)$ & $136.2^{\mathrm{a}}$ & $133.7^{\mathrm{a}}$ & $102.6^{\mathrm{b}}$ & $86.3^{\mathrm{c}}$ & 3.5 \\
Ratio: intake of water to feed (ml/g DM) & $2.6^{\mathrm{a}}$ & $2.5^{\mathrm{a}}$ & $1.8^{\mathrm{b}}$ & $1.5^{\mathrm{c}}$ & 0.05 \\
Average daily gain (g/day) & $85.5^{\mathrm{a}}$ & $81.9^{\mathrm{a}}$ & $64.3^{\mathrm{b}}$ & $65.6^{\mathrm{b}}$ & 1.41 \\
Feed conversion efficiency (g feed/g gain) & $9.3^{\mathrm{b}}$ & $9.3^{\mathrm{b}}$ & $12.1^{\mathrm{a}}$ & $12.1^{\mathrm{a}}$ & 3.43 \\
\hline
\end{tabular}

${ }_{\mathrm{a}, \mathrm{b}, \mathrm{c}}$ Row means with different superscripts differ significantly $(p<0.05)$

Apparent digestibility (\%) of organic matter decreased (Table 4) from 66.8 for the ad lib treatment to 65.5 for the $72 \mathrm{~h}$ treatment $(p<0.01)$. Similar responses occurred for dry matter digestibility (Table 4$)$. Crude protein digestibility decreased from 67.6 to 62.4 from the ad lib to the $72 \mathrm{~h}$ treatment $(p<0.01)$; crude fibre digestibility showed a similar trend but no differences occurred between the $a d l i b$ and $24 \mathrm{~h}$ treatments or between the $48 \mathrm{~h}$ and $72 \mathrm{~h}$ treatments $(p>0.05)$.

Table 4 Effect of water deprivation on digestibility parameters in Tswana goats subject to varying lengths of water deprivation

\begin{tabular}{lccccc}
\hline & \multicolumn{4}{c}{ Watering interval } \\
& Adlib & 24 hour & 48 hour & 72 hour & s.e. \\
& & & & & \\
\hline Feed intake (kg/day) & $1.08^{\mathrm{a}}$ & $0.99^{\mathrm{ab}}$ & $0.81^{\mathrm{c}}$ & $0.90^{\mathrm{bc}}$ & 0.035 \\
Water intake (ml/day) & $3200^{\mathrm{a}}$ & $1546^{\mathrm{b}}$ & $1252^{\mathrm{c}}$ & $1022^{\mathrm{d}}$ & 55.0 \\
& & & & & \\
Digestibility (\%) & & & & \\
Dry matter & $66.8^{\mathrm{a}}$ & $66.7^{\mathrm{a}}$ & $64.2^{\mathrm{b}}$ & $65.2^{\mathrm{b}}$ & 0.39 \\
Organic mater & $66.8^{\mathrm{a}}$ & $66.6^{\mathrm{ab}}$ & $64.4^{\mathrm{c}}$ & $65.5^{\mathrm{bc}}$ & 0.41 \\
Crude protein & $67.6^{\mathrm{a}}$ & $66.6^{\mathrm{b}}$ & $64.3^{\mathrm{c}}$ & $62.4^{\mathrm{d}}$ & 0.33 \\
Crude fibre & $66.5^{\mathrm{a}}$ & $66.3^{\mathrm{a}}$ & $64.1^{\mathrm{b}}$ & $63.9^{\mathrm{b}}$ & 0.40 \\
& & & & & \\
Faecal output (g DM/day) & $403.6^{\mathrm{a}}$ & $376.2^{\mathrm{ab}}$ & $336.7^{\mathrm{c}}$ & $358.7^{\mathrm{bc}}$ & 12.22 \\
Faecal water content (g/kg DM) & $159.8^{\mathrm{a}}$ & $135.9^{\mathrm{b}}$ & $119.6^{\mathrm{c}}$ & $115.2^{\mathrm{c}}$ & 4.35 \\
Faecal water output (g/kg W $\left.{ }^{0.75}\right)$ & $13.5^{\mathrm{a}}$ & $11.7^{\mathrm{b}}$ & $10.9^{\mathrm{c}}$ & $9.4^{\mathrm{d}}$ & 0.25 \\
Urine output (ml/day) & $781.9^{\mathrm{a}}$ & $460.1^{\mathrm{b}}$ & $366.5^{\mathrm{c}}$ & $294.8^{\mathrm{d}}$ & 21.66 \\
Water intake/urine output & $4.12^{\mathrm{a}}$ & $3.77^{\mathrm{a}}$ & $3.83^{\mathrm{a}}$ & $4.15^{\mathrm{a}}$ & 0.37 \\
\hline a,b,c Row means with different superscripts differ significantly $(p<0.05)$ & & &
\end{tabular}

A water medium is needed both for the physical softening of feed and the biochemical digestion of feed. An adequate supply of water could therefore aid the breakdown of feed and hence facilitate the fermentation and digestion processes. This could account for the higher digestibility observed when watering was more frequent. Furthermore, numbers of rumen bacteria and protozoa tend to decrease following water deprivation (Fluharty et al. 1996), and this could also have contributed to the lowered digestibility at less frequent watering intervals. These differences in digestibility could account 
for the differences in feed conversion efficiency and daily gains (Table 3), and support the findings of Umunna et al. (1981) and Aganga (1992), who also reported a decrease in weight gains as watering frequency was increased. The digestibility indices, however, conflict with reports by Devendra (1971) who observed increased digestibility as length of water deprivation increased. Furthermore, Thornton \& Minson (1973) and Merchen et al. (1977) found a decrease in organic matter and crude protein digestibility as a result of lowered retention time due to increased dry matter intake. This could also have occurred in this study.

There was no clear effect of water deprivation on feed intake (Table 4), possibly due to the short duration of the digestion study. Volume of urine voided decreased $(p<0.01)$ with increasing level of water deprivation. The ratio of water intake to urine voided was, however, similar $(p>0.05)$ for all treatments (Table 4) which means that goats voided volumes of urine proportional to the volume of water drunk. This agrees with the report of Aganga et al. (1988) and would result in less moisture loss by the water-deprived animals. Faecal moisture content also decreased $(p<0.01)$ with increased water deprivation, suggesting that animals were able to adjust their water output to their water intake.

Water deprivation tended to cause some physiological stress to animals at the $72 \mathrm{~h}$ watering interval (Table 5). Although rectal temperature did not differ between treatments $(p>0.05)$, MCHC tended to be higher, whilst respiratory rate, pulse rate and PCV were highest $(p<0.01)$ at the $72 \mathrm{~h}$ watering interval. Haemoglobin concentration was highest at the $48 \mathrm{~h}$ and $72 \mathrm{~h}$ watering intervals $(p<0.01)$. These observations suggest that water deprivation raised the concentrations of blood biochemical constituents due to dehydration at the $72 \mathrm{~h}$ watering interval (Table 5).

Table 5 Effect of water deprivation on health indicators in Tswana goats

\begin{tabular}{llllll}
\hline & \multicolumn{5}{c}{ Watering interval } \\
& Ad lib & 24 hour & 48 hour & 72 hour & s.e. \\
\hline Rectal Temperature $\left({ }^{\circ} \mathrm{C}\right)$ & 38.3 & 38.3 & 38.3 & 38.3 & 0.09 \\
Respiratory rate (breaths/min) & $15.9^{\mathrm{b}}$ & $15.6^{\mathrm{b}}$ & $16.1^{\mathrm{b}}$ & $17.3^{\mathrm{a}}$ & 0.29 \\
Pulse rate (beats/min) & $89.5^{\mathrm{a}}$ & $86.2^{\mathrm{b}}$ & $86.7^{\mathrm{ab}}$ & $80.1^{\mathrm{c}}$ & 1.12 \\
Haemoglobin $(\%)$ & $9.6^{\mathrm{b}}$ & $9.8^{\mathrm{b}}$ & $10.5^{\mathrm{a}}$ & $10.6^{\mathrm{a}}$ & 0.13 \\
Packed cell volume (\%) & $24.5^{\mathrm{b}}$ & $25.1^{\mathrm{b}}$ & $25.9^{\mathrm{ab}}$ & $26.5^{\mathrm{a}}$ & 0.51 \\
Corpuscular haemoglobin concentration $(\%)$ & $40.4^{\mathrm{c}}$ & $41.1^{\mathrm{bc}}$ & $43.1^{\mathrm{a}}$ & $42.4^{\mathrm{ab}}$ & 0.57
\end{tabular}

${ }_{\mathrm{a}, \mathrm{b}, \mathrm{c}}$ Row means with different superscripts differ significantly $(p<0.05)$

Table 6 Effect of season on feed and water intake of Tswana goats subject to varying lengths of water deprivation

\begin{tabular}{llll}
\hline & \multicolumn{3}{c}{ Season } \\
& Winter & Summer & s.e. \\
\hline Feed intake (g DM/day) & $657^{\mathrm{b}}$ & $828^{\mathrm{a}}$ & 15.9 \\
Feed intake $\left(\mathrm{g} \mathrm{DM} / \mathrm{kgW}^{0.75}\right)$ & $63.6^{\mathrm{a}}$ & $57.6^{\mathrm{b}}$ & 1.13 \\
Free-water intake $(\mathrm{ml} /$ day) & $950^{\mathrm{b}}$ & $1889^{\mathrm{a}}$ & 48.9 \\
Feed-water intake $(\mathrm{ml} / \mathrm{day})$ & $55.2^{\mathrm{b}}$ & $69.5^{\mathrm{a}}$ & 1.34 \\
Total water intake (ml/day) & $1005^{\mathrm{b}}$ & $1959^{\mathrm{a}}$ & 49.6 \\
Total water intake (ml/kg W $\left.{ }^{0.75}\right)$ & $97.8^{\mathrm{b}}$ & $134.3^{\mathrm{a}}$ & 3.5 \\
Ratio of intake of water to feed (ml/gDM) & $1.6^{\mathrm{b}}$ & $2.4^{\mathrm{a}}$ & 0.05 \\
Average daily gain $(\mathrm{g} /$ day) & $75.9^{\mathrm{a}}$ & $69.2^{\mathrm{b}}$ & 1.41 \\
Feed conversion efficiency (g feed/g gain) & $9.3^{\mathrm{b}}$ & $12.4^{\mathrm{a}}$ & 3.43 \\
\hline a,b,c Row means with different superscripts differ significantly $(p<0.05)$ & &
\end{tabular}

Because animals drank less water in winter (Table 6), they consumed more feed, converted feed more efficiently and gained more weight $(p<0.01)$ in winter than in summer. This may be due to the rumen-fill effect discussed above. Rectal temperature and respiratory rate did not differ $(p>0.05)$ between seasons, and indicates thermoregulatory adaptation to the extremes of temperature occuring in this region. However, pulse rate, haemoglobin concentration and PCV were higher $(p<0.05)$ in winter than in summer, and MCHC was lower $(p<0.01)$ in winter than in summer (Table 7), 
suggesting that animals experienced higher levels of dehydration in summer than in winter, probably due to water loss by thermoregulatory mechanisms and direct evaporation.

Table 7 Effect of season on health indicators in Tswana goats subject to varying lengths of water deprivation

\begin{tabular}{llll}
\hline & \multicolumn{2}{c}{ Season } \\
& Winter & Summer & s.e. \\
\hline Temperature $\left({ }^{\circ} \mathrm{C}\right)$ & 38.2 & 38.3 & 0.09 \\
Respiratory rate (breaths/min) & 16.2 & 16.7 & 0.29 \\
Pulse rate (beats/min) & $88.4^{\mathrm{a}}$ & $82.9^{\mathrm{b}}$ & 1.12 \\
Haemoglobin $(\%)$ & $10.8^{\mathrm{a}}$ & $10.2^{\mathrm{b}}$ & 0.13 \\
Packed cell volume (\%) & $33.7^{\mathrm{a}}$ & $20.9^{\mathrm{b}}$ & 0.51 \\
Corpuscular haemoglobin & $32.1^{\mathrm{b}}$ & $48.7^{\mathrm{a}}$ & 0.57 \\
concentration $(\%)$ & & \\
${ }_{\mathrm{a}, \mathrm{b}, \mathrm{c}}$ Row means with different superscripts differ significantly $(p<0.05)$
\end{tabular}

\section{Conclusions}

It was concluded that that goats are more at risk to water deprivation in summer than in winter and that goats can be watered once in 72 hours without severe dehydration. The tolerance of indigenous goats to water deprivation may be due to their ability to limit urine and faecal water excretion.

\section{References}

Aganga, A.A., 1992. Water utilization by sheep and goats in Northern Nigeria. World Animal Review. FAO 73, 9-14. Aganga, A.A., Alabi, O. \& Momoh, M., 1988. Effect of water deprivation on nutrient digestibility, nitrogen retention, and water excretion in Yankasa sheep and Maradi goats. Nigerian J. Anim. Prod. 15, 139-143

AOAC, 1995. Association of official analytical chemists. Official methods of analysis. 16th Edition, Arlington, Virginia, USA.

Campling, R.C., Freer, M. \& Balch, C.C., 1961. Factors affecting the voluntary intake of food by cows. 2. The relationship between voluntary intake of roughages, the amount of digesta in the reticulo-rumen and the rate of disappearance of digesta from the alimentary tract. Br. J. Nutr. 15, 531-536.

CSO, 1995. 1993 Botswana agricultural census report. Ministry of agriculture and ministry of finance and development planning. Government Printer, Gaborone, Botswana. 178pp

Devendra, C., 1971. The comparative efficiency of feed utilization of ruminants in the tropics. Trop. Sci. 13, 123-132.

Fluharty, F.L., Loerch, S.C. \& Dehority, P., 1996. Effects of feed and water deprivation on ruminal characteristics and microbial population of newly weaned and feedlot-adopted calves. J. Anim. Sci. 74, 465-474

Ikhatua, U. J., Ehoche, O.W. \& Umoh, J.E., 1985. Effects of restricted water on feed intake, nutrient utilisation, and nitrogen metabolism in zebu cattle. J. Agric. Sci. Camb. 105, 463-467.

Jurgens, H.M., 1977. Animal feeding and nutrition. 7th edition. Kendal Hunt Publishing Company. USA.

Mead, R. \& Curnow, R.N., 1992. Statistical methods in agriculture and experimental biology. Chapman and Hall. London.

Merchen, N.R., Elizalde, J.C. \& Drackley, J.K., 1997. Current perspectives on assessing site of digestion in ruminants. J. Anim. Sci. 75, 2223-2234

SAS, 1990. Statistical Analysis Systems Institute Inc. SAS procedures guide, release 6.03. Cary, NC

Schoen, A., 1968. Studies on the water balance of the East African goat. East Afr. Agric. For. J. 34, 256-262.

Sibanda, S., Hatendi, P.R., Mulenga, P.R. \& Ndlovu, P., 1977. The effect of diet and frequency of watering on rumen degradability and outflow rate of low quality veld hay and dry matter apparent digestibility in steers given food at maintenance. Anim. Sci. 65, 159-164.

Thornton, R.F. \& Minson, D.J., 1973. The relationship between apparent retention time in the rumen, voluntary intake and apparent digestibility of legume and grass diets in sheep. Aust. J. Agric. Res. 24, 889-898.

Umunna, N.N., Chineme, C.N., Saror, D.I., Ahmed, A. \& Abed, S., 1981. Response of Yankasa sheep to various lengths of water deprivation. J. Agric. Sci. Camb. 96, 619-622.

Utley, P.R., Bradley, N.W. \& Boling, J., 1970. Effect of restricted water intake on feed intake, nutrient digestibility and nitrogen metabolism in steers. J. Anim. Sci. 31, 130-135. 